Research Paper

\title{
The Increase in Mannose Receptor Recycling Favors Arginase Induction and Trypanosoma Cruzi Survival in Macrophages
}

\author{
Vanina V. Garrido, Laura R. Dulgerian, Cinthia C. Stempin, Fabio M. Cerbán ${ }^{凶}$ \\ CIBICI-CONICET. Dpto. Bioquímica Clínica. Facultad de Ciencias Químicas. Universidad Nacional de Córdoba. Argentina.
}

Corresponding author: Fabio M. Cerbán. CIBICI-CONICET. Departamento de Bioquímica Clínica. Facultad de Ciencias Químicas. Universidad Nacional de Córdoba. Haya de la Torre y Medina Allende s/n. Ciudad Universitaria. 5000. Córdoba. Argentina. Tel: +54-351-4344973. Fax: +54-351-4333048. E-mail addresses: fcerban@fcq.unc.edu.ar or fmcerban@hotmail.com

( ) Ivyspring International Publisher. This is an open-access article distributed under the terms of the Creative Commons License (http://creativecommons.org/ licenses/by-nc-nd/3.0/). Reproduction is permitted for personal, noncommercial use, provided that the article is in whole, unmodified, and properly cited.

Received: 2011.09.01; Accepted: 2011.10.01; Published: 2011.10.25

\begin{abstract}
The macrophage mannose receptor (MR) is a pattern recognition receptor of the innate immune system that binds to microbial structures bearing mannose, fucose and $\mathrm{N}$-acetylglucosamine on their surface. Trypanosoma cruzi antigen cruzipain $(\mathrm{Cz})$ is found in the different developmental forms of the parasite. This glycoprotein has a highly mannosylated C-terminal domain that participates in the host-antigen contact. Our group previously demonstrated that $\mathrm{Cz}$-macrophage (Mo) interaction could modulate the immune response against $T$. cruzi through the induction of a preferential metabolic pathway. In this work, we have studied in Mo the role of MR in arginase induction and in T. cruzi survival using different $M R$ ligands. We have showed that pre-incubation of $T$. cruzi infected cells with mannose-Bovine Serum Albumin (Man-BSA, MR specific ligand) biased nitric oxide (NO)/urea balance towards urea production and increased intracellular amastigotes growth. The study of intracellular signals showed that pre-incubation with Man-BSA in T. cruzi $J 774$ infected cells induced down-regulation of JNK and p44/p42 phosphorylation and increased of p38 MAPK phosphorylation. These results are coincident with previous data showing that $\mathrm{Cz}$ also modifies the MAPK phosphorylation profile induced by the parasite. In addition, we have showed by confocal microscopy that $\mathrm{Cz}$ and Man-BSA enhance MR recycling. Furthermore, we studied MR behavior during T. cruzi infection in vivo. MR was up-regulated in F4/80+ cells from $T$. cruzi infected mice at 13 and I 5 days post infection. Besides, we investigated the effect of MR blocking antibody in T. cruzi infected peritoneal Mo. Arginase activity and parasite growth were decreased in infected cells pre-incubated with anti-MR antibody as compared with infected cells treated with control antibody. Therefore, we postulate that during T. cruzi infection, $\mathrm{Cz}$ may contact with MR, increasing MR recycling which leads to arginase activity up-regulation and intracellular parasite growth.
\end{abstract}

Key words: T. cruzi, macrophage, arginase, iNOS, mannose receptor.

\section{Introduction}

Trypanosoma cruzi, an obligate intracellular protozoan parasite, is the etiological agent of human Chagas disease, a widely distributed debilitating infection, which constitutes a major health problem in Latin American countries. This parasite infects a wide range of host cell types including Mo [1]. The ability of $T$. cruzi to infect and replicate within a variety of cell types is an essential feature of its cycle.

Mo are important effector cells involved in various phases of immune responses, such as phagocytosis, antigen presentation, and secretion of bioactive molecules $[2,3]$. Mo may either inhibit T. cruzi repli- 
cation or provide a favorable environment in which it can multiply and be disseminated to other sites within the body [1]. However, pathogens have developed several strategies to circumvent microbicidal responses of host cells. It has been postulated that phagocytosis through receptors that bypass the bactericidal activity of Mo may provide an opportunity for pathogens to manipulate the host environment to their own advantage $[4,5]$.

Mo exposure to Th1 cytokines or bacterial products such as LPS or CpG DNA, induces classical activated Mo that produce NO. This provides a key defensive element in various infectious diseases. In contrast, Mo differentiated in the presence of Th2 cytokines have enhanced capacity for endocytosis but do not exert enhanced killing functions towards microbes [6, 7]. Furthermore, NO production is counteracted by the expression of arginase, an enzyme that competes with inducible nitric oxide synthase (iNOS) for L-arginine that leads to L-ornithine and urea production [8].

Cruzipain $(\mathrm{Cz})$, one of the immunodominant antigens of T. cruzi, is a glycoprotein of about $52-58 \mathrm{kDa}$ that has both high mannose- and complex-type-N-linked glycans at the C-terminal domain [9-12]. It is found in every developmental form of parasites [13] and it has been reported to be highly immunogenic in human infection [12, 14]. Moreover, it has been shown that mice-immunization with $\mathrm{Cz}$ elicits humoral and cellular immune responses [15]. Given that the activation of arginase may be an effective mechanism for regulating $\mathrm{NO}$ production in Mo, we previously investigated the influence of L-arginine catabolism on $T$. cruzi growth through the interaction of Mo with $\mathrm{Cz}$ [16-18]. We showed that $\mathrm{Cz}$ induced alternative activation of Mo in vitro and up-regulated arginase activity. This Mo activation profile was associated with the functional ability of these cells to promote the intracellular growth of T. cruzi [16]. In addition, we previously demonstrated that $\mathrm{Cz}$ induced arginase through the activation of multiple signaling pathways including Tyrosine Kinase (TK), Protein Kinase A (PKA) and p38 MAPK [17, 18].

On the other hand, protein expression studies and transcriptional profiling have shown that IL-4 induces up-regulation of the MR and other several receptors on monocytes and Mo [19-23], while MR is down-regulated in classically activated Mo [24]. MR is a multi-domain protein composed of a cysteine-rich domain with lectin activity that binds to sulphated sugars, a fibronectin type-II (FNII) domain that mediates binding to collagen [25] and eight C-type-lectin-like domains (or carbohydrate-recognition domains, CRD). The fourth CRD mediates most of the specificity of these domains for glycans terminating in mannose, fucose and $\mathrm{N}$-acetyl glucosamine. In addition to many endogenous ligands, MR binds to bacteria (e.g. Mycobacterium tuberculosis), fungi (e.g. Pneumocystis carinii) and viruses (e.g. HIV). MR is expressed on the surface of Mo, dendritic cells (DC) and some epithelial cells. In addition, it is constitutively internalized from the plasma membrane by clathrin-mediated endocytosis and recycled back to the cell surface [26]. Receptor-ligand dissociation occurs under the influence of low $\mathrm{pH}$ within endosomal membrane vesicles. A proportion of internalized receptor-ligand complexes fail to dissociate, and are returned to the cell surface intact, suggesting the presence of alternative endocytosis pathways [27, 28]. Intracellular targeting is mediated by a tyrosine-based motif in the cytoplasmic tail, although it contains no recognized signalling motifs [29]. MR-pathogen interactions have been implicated in the initiation of signaling pathways leading to the production of lysosomal enzymes [30], reactive oxygen and nitrogen molecules [31, 32] and IL-1, IL-6, GM-CSF [33], TNFa [34] and IL-12 [35]. In addition, MR has also been implicated in the delivery of antigens to intracellular compartments containing MHC class II molecules participating in foreign antigens presentation [36].

Given that, MR has been implicated in the recognition of several pathogens by Mo [19] and it has been associated with Mo alternative activation, in this work we studied the role of MR in arginase induction and T. cruzi survival in Mo using different MR ligands.

\section{Materials and Methods}

\section{Parasites and infection protocols}

T. cruzi epimastigote forms from Tulahuen strain were grown at $28{ }^{\circ} \mathrm{C}$ in brain heart infusion supplemented with $0.5 \%$ tryptose (Becton Dickinson), $10 \%$ FCS, $200 \mathrm{mg} / \mathrm{ml}$ hemin, $100 \mathrm{U} / \mathrm{ml}$ penicillin, and 100 $\mathrm{mg} / \mathrm{ml}$ streptomycin. Parasites were harvested at the exponential growth phase, then centrifuged at $5000 \times g$ for $10 \mathrm{~min}$ at $4{ }^{\circ} \mathrm{C}$, and washed with PBS.

T. cruzi trypomastigote (Tp) forms were maintained by serial passage in BALB/c mice (Comisión Nacional de Energía Atómica, Buenos Aires, Argentina). Male BALB/c mice, 6-8 weeks old, were intraperitoneally infected with $500 \mathrm{~T}$. cruzi Tp forms diluted in PBS. The studies are approved by the Institutional Review Board and Ethical Committee of the School of Chemical Sciences, National University of Córdoba, Argentina. 


\section{Antigen}

Cruzipain purification: T. cruzi epimastigote forms from Tulahuen strain were grown at $28{ }^{\circ} \mathrm{C}$ in brain heart infusion (Becton Dickinson, France) supplemented with $0.5 \%$ tryptose, $10 \%$ FCS, $200 \mathrm{mg} / \mathrm{ml}$ hemin, $100 \mathrm{U} / \mathrm{ml}$ penicillin, and $100 \mathrm{mg} / \mathrm{ml}$ streptomycin. Parasites were harvested at the exponential growth phase, centrifuged at $5000 \times g$ for $10 \mathrm{~min}$ at $4^{0} \mathrm{C}$, and washed with PBS. Parasites were resuspended in $3 \mathrm{vol}$ of $0.25 \mathrm{M}$ sucrose, $5 \mathrm{mM} \mathrm{KCl}$ and the following irreversible protease inhibitors: $1 \mathrm{mM}$ TLCK and 1 mM PMSF (Sigma Chemical Co., St. Louis, MO, USA). The epimastigotes were disrupted by three cycles of freezing $(-20 \circ \mathrm{C})$ and thawing $(4 \circ \mathrm{C})$, and the homogenates were centrifuged at $7000 \times g$ for $15 \mathrm{~min}$ at $4{ }^{\circ} \mathrm{C}$. Saturated ammonium sulfate solution, adjusted to $\mathrm{pH}$ 7 with $\mathrm{NH} 4 \mathrm{OH}$, was added at $50 \%$ saturation to the supernatant, with stirring in an ice bath [10]. The precipitate obtained after centrifugation of this suspension was carefully dissolved and dialyzed in a solution with $50 \mathrm{mM}$ Tris- $\mathrm{HCl}, 150 \mathrm{mM} \mathrm{NaCl}, \mathrm{pH} 7.4$. $\mathrm{CaCl} 2, \mathrm{MgCl} 2$ and $\mathrm{MnCl} 2$ were added to the dialyzed solution to provide a final concentration of $5 \mathrm{mM}$ for each salt. Subsequently, the samples were submitted to affinity chromatography as previously described [37]. The absence of enzyme activity was checked by $10 \%$ SDS-PAGE containing $0.1 \%$ gelatin as substrate. After the electrophoresis performed at $120 \mathrm{~V}$, the gel was incubated with $50 \mathrm{mM}$ sodium phosphate buffer $\mathrm{pH} 5.7$ at $37{ }^{\circ} \mathrm{C}$ overnight, and stained with Coomassie Brilliant Blue R250. The samples were neither reduced nor boiled [38]. Lipopolyssacharide (LPS) contamination of this preparation was ruled out using the Limulus assay (BioWhittaker).

\section{Cell cultures}

The murine Mo cell line J774 was cultured in RPMI 1640 containing 10\% fetal bovine serum (FBS), $4 \mathrm{mM}$ glutamine and $40 \mu \mathrm{g} / \mathrm{ml}$ gentamycin at $37^{\circ} \mathrm{C}$ in $5 \% \mathrm{CO} 2$.

\section{Resident peritoneal cells culture}

Normal resident peritoneal cells from BALB/c mice were obtained by several peritoneal washings with complete RPMI medium.

\section{Cells treatment}

J774 or peritoneal cells were incubated with increasing concentrations of mannan from Saccharomyces cerevisiae (Sigma-Aldrich, Saint Louis MO, USA), a-mannopyranoside (Sigma-Aldrich), mannose-BSA (Sigma-Aldrich) or EDTA (Sigma-Aldrich) for $2 \mathrm{~h}$. Then cells were infected by exposure to $T$. cruzi Tp forms for $24 \mathrm{~h}$. Cells were subsequently washed for removing the non-internalized parasites.

\section{Determination of arginase activity}

J774 cells $\left(1 \times 10^{6} / \mathrm{ml}\right)$ or peritoneal cells $\left(1 \times 10^{6} / \mathrm{ml}\right)$ were treated as previously described above. Arginase activity was measured in cell lysates as described previously [16, 39]. Briefly, cells were lysed with $50 \mu \mathrm{l}$ of $0.1 \%$ Triton X-100 containing protease inhibitors. This mixture was stirred for $30 \mathrm{~min}$ and then $50 \mu \mathrm{l}$ of $10 \mathrm{mM} \mathrm{MnCl} 2$ with $50 \mathrm{mM}$ Tris- $\mathrm{HCl}$ we added to activate the enzyme for $10 \mathrm{~min}$ at $56{ }^{\circ} \mathrm{C}$. Arginine hydrolysis was initiated by the addition of $25 \mu \mathrm{l}$ of $0.5 \mathrm{M}$ L-arginine, $\mathrm{pH} 9.7$, at $37 \circ \mathrm{C}$ for $45 \mathrm{~min}$. The reaction was stopped with a mixture of acids, and the urea concentration was measured at $540 \mathrm{~nm}$ after the addition of $25 \mu \mathrm{l}$ of a-isonitrosopropiophenone (dissolved in 100\% ethanol) followed by heating at 95 - $\mathrm{C}$ for $45 \mathrm{~min}$. The results are expressed as Arginase Index (fold increase of arginase activity in samples above basal).

\section{NO assay}

J774 cells $\left(1 \times 10^{6}\right.$ cells/well $)$ were treated as previously described above. Supernatants were collected at $48 \mathrm{~h}$ and mixed with an equal volume of Griess reagent [40]. Optical density measurements were averaged and converted to micromoles of nitrites per well using a standard curve of sodium nitrite. Results are expressed as Nitrites Index (fold increase of nitrites in samples above basal).

\section{Trypanocidal activity}

J774 cells $\left(2 \times 10^{5} / \mathrm{ml}\right)$ were treated as previously described above and infected with T. cruzi Tp at three parasites per cell ratio and were cultured for $48 \mathrm{hr}$ at $37{ }^{\circ} \mathrm{C}$ in a humidified $5 \% \mathrm{CO}_{2}$ atmosphere. After $24 \mathrm{hr}$, cells were washed to remove extracellular parasites. The number of parasites was determined by indirect immunofluorescence [16]. The slides were taken $72 \mathrm{~h}$ later; washed three times with PBS and fixed in $4 \%$ formol-PBS for $45 \mathrm{~min}$. Then, they were treated with $1 \%$ Triton X-100 for 15 min. After washing with PBS, the slides were blocked with $1 \%$ PBS-BSA for $15 \mathrm{~min}$. Subsequently, the slides were incubated overnight at $4{ }^{\circ} \mathrm{C}$ with positive Chagas serum diluted with PBS. Slides were washed and FITC-labelled anti-human IgG was added in $1 \%$ PBS-BSA. After $1 \mathrm{hr}$, slides were washed three times with PBS and were mounted on PBS-Glycerin. The results are expressed as Amastigotes number Index (fold increase of amastigotes number in samples above that of non-treated infected cells). 


\section{Western blot analysis}

J774 cells $\left(1 \times 10^{6}\right)$ were pretreated with Man-BSA or mannan for $2 \mathrm{~h}$ and then incubated with the parasite for during $30 \mathrm{~min}$. Following these treatments the cells were lysed and Western blot analysis was performed as previously described [16]. Membranes were probed by using the rabbit antibody anti-phospho p38, anti-phospho p44/p42, anti-phospho JNK at 1:1000 dilution (Cell Signaling Technology, Beverly, MA, USA) and $\beta$-actin at 1:1000 dilution (Cell Signaling Technology) followed by anti-rabbit peroxidase conjugated (Sigma-Aldrich) at 1:1000 dilution. Bands were visualized using a chemiluminescence reaction (Amersham Biosciences, UK).

\section{Flow cytometry}

MR recycling: J774 or peritoneal cells (1x106 cells/well) were incubated for $15,30,60,90,120$, 150 and $180 \mathrm{~min}$ with FITC-Man-BSA $(500 \mathrm{ng} / \mathrm{ml})$ (Sigma-Aldrich) or IL-13 (BD Biosciences) for $180 \mathrm{~min}$ at room temperature. Then, cells were washed for removing not bound FITC-Man-BSA and fixed. On the other hand, J774 cells $\left(1 \times 10^{6}\right.$ cells/well $)$ were treated with $\mathrm{Cz}(25,50$ or $75 \mathrm{ug} / \mathrm{ml})$ during $2 \mathrm{~h}$ and then incubated with FITC-Man-BSA (500 ng/ml) for $20 \mathrm{~min}$. Then cells were washed to remove unbound FITC-Man-BSA and fixed. FITC+ cells were analyzed by flow cytometry (FACS Canto II, BD Biosciences, San Jose, CA). Results were analyzed using FACS-DIVA software (BD Biosciences).

Ex vivo studies: Peritoneal cells from T. cruzi infected BALB/c mice were removed at 13 and 15 days post infection. In addition peritoneal cells from non-infected BALB/c mice were used as control. Cells were incubated with FITC-labeled Man-BSA and PE-labeled anti-mouse F4/80 antibody (BD Biosciences, Pharmingen, San Diego, CA). After $20 \mathrm{~min}$, cells were washed to remove unbound FITC-labeled Man-BSA and PE-labeled anti-F4/80 antibodies. FITC+ PE + cells were analyzed by flow cytometry.

Interaction $\mathrm{Cz}-\mathrm{MR}$ : Peritoneal cells from BALB/c mice were incubated for $30 \mathrm{~min}$ with $\mathrm{Cz}(50 \mathrm{ug} / \mathrm{ml})$, Man-BSA $(750 \mathrm{ng} / \mathrm{ml})$ or BSA $(750 \mathrm{ng} / \mathrm{ml})$ (Sigma-Aldrich). Peritoneal cells were washed and fixed. Then, cells were incubated for $30 \mathrm{~min}$ with FITC-labeled anti-MR antibody $(10 \mathrm{ug} / \mathrm{ml}$, Santa Cruz Biotechnology, Santa Cruz, CA). FITC+ cells were analyzed by flow cytometry.

Acidic solution treatment: J774 cells were incubated for $3 \mathrm{~h}$ with FITC-Man-BSA at room temperature. After incubation, cells were washed with regular buffer or with acidic solution (Glycin- $\mathrm{HCl} \mathrm{pH}: 2,7)$ to remove FITC-Man-BSA on the cell surface.

\section{Confocal Microscopy}

J774 cells on glass coverslips were incubated for 1,2 or $3 \mathrm{~h}$ with FITC-Man-BSA (500 ng/ml) or FITC-Cz $(50 \mathrm{ug} / \mathrm{ml})$ at $4{ }^{\circ} \mathrm{C}$ or room temperature. Then, cells were treated with regular buffer or with acidic solution and they were analyzed by confocal microscopy (FV-300, Olympus, Miami, FL).

\section{Statistical analysis}

The Mann-Whitney $U$-test was used to compare the data corresponding to treated and non-treated groups. A $p$-value $<0.05$ was considered as statistically significant.

\section{Results}

Man-BSA modifies iNOS/arginase balance favoring Trypanosoma cruzi survival in macrophages.

We have previously demonstrated that the interaction between $\mathrm{Cz}$ and Mo could modulate the immune response against $T$. cruzi through the induction of a preferential metabolic pathway in Mo. To investigate whether MR is involved in arginine metabolism in T. cruzi-infected Mo, J774 cells were incubated with increasing concentrations of different MR-ligands such as mannan from Saccharomyces cerevisiae (mannan), a-mannopyranoside (aMM), Man-BSA or EDTA (Ca++ sequester) for $2 \mathrm{~h}$. Subsequently, cells were infected by exposure to T. cruzi Tp forms for $24 \mathrm{~h}$ and afterward they were washed to remove the non-internalized parasites. After $48 \mathrm{~h}$ urea or nitrite concentrations were measured in cell lysates or in culture supernatants, respectively.

Man-BSA pre-incubated Mo showed a higher level of urea than control cells. In contrast, EDTA pre-incubated Mo showed lower urea levels as compared with control cells (Fig. 1A). In addition, mannan or aMM pre-incubated Mo did not show changes in urea levels as compared with control cells. Besides, we did not observed changes in urea levels in MR-ligand pre-treated and in non-infected cells. Moreover, we obtained similar results using peritoneal cells (data not shown). Furthermore, these results were consistent with iNOS activity. Man-BSA pretreated Mo showed lower nitrites levels than control cells. In contrast, mannan and aMM pretreated cells did not show differences in nitrites production as compared with control cells (Fig. 1B). 

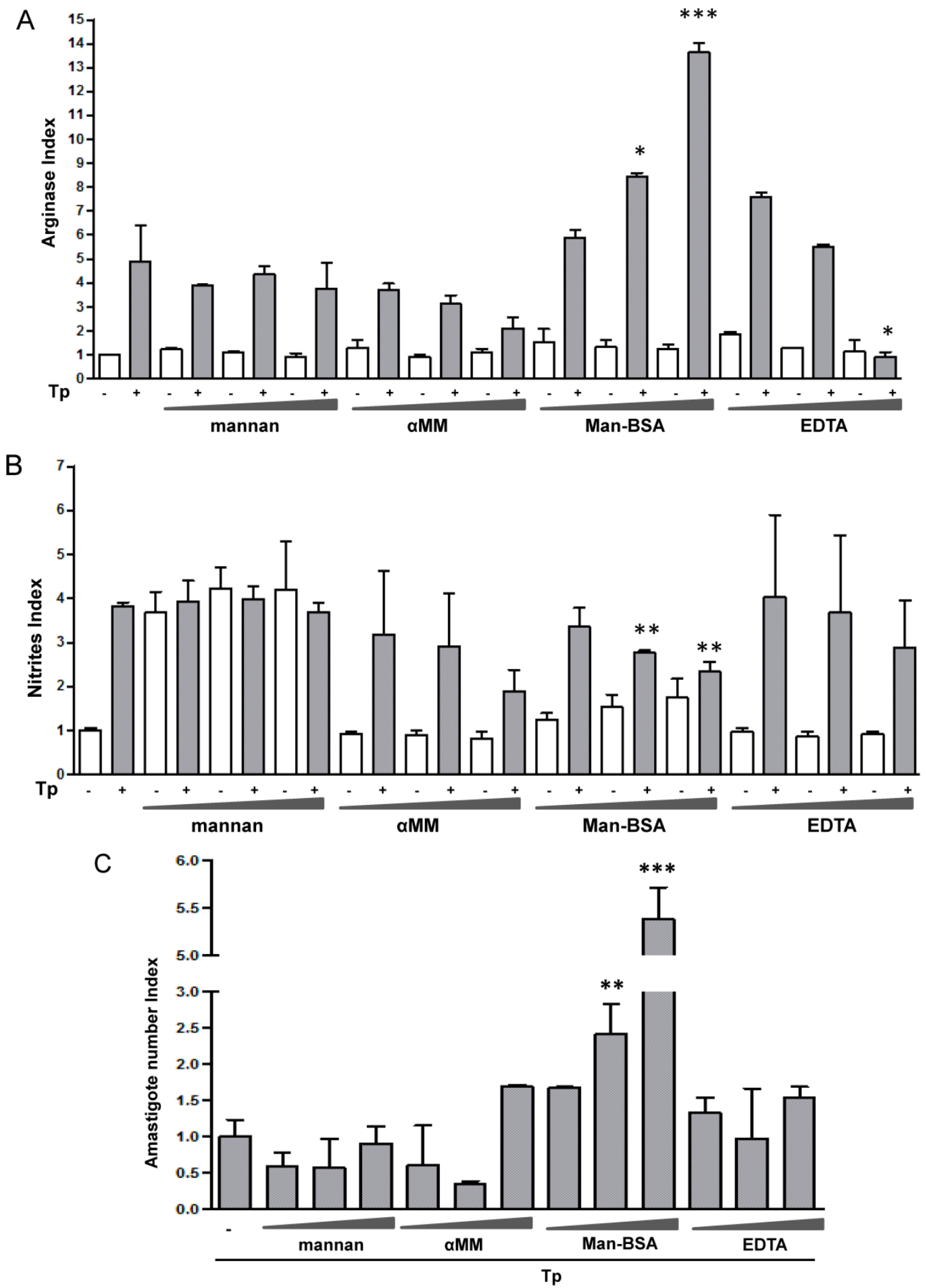

Figure I. Man-BSA modifies the balance NO/arginase favoring the survival of $T$. cruzi in Mo. $J 774$ cells $\left(\right.$ Ix $10^{6} \mathrm{cells} /$ well) were plated and incubated for $2 \mathrm{~h}$ with increased concentrations of mannan of Saccharomyces cerevisiae

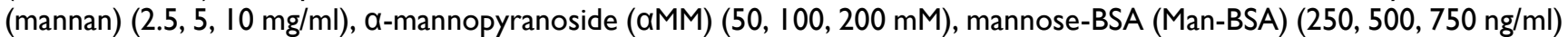
or EDTA (0.5, I, $2 \mathrm{mM}$ ). Then, cells were infected with T. cruzi Tp forms (three parasites per cell). After $18 \mathrm{~h}$, cells were washed to remove the non-internalized parasites. After $48 \mathrm{~h}$, arginase activity was evaluated measuring urea levels in macrophage lysates (A) and iNOS activity was also examined by measuring nitrites levels in culture supernatants (B); infected (grey bars) and non infected cells (white bars). Peritoneal cells $\left(2 \times 10^{5}\right.$ cells/well) were plated on 12 -mm round-glass coverslips and were treated in the same form described above. The number of amastigotes/l00 cells was counted after $72 \mathrm{~h}$ using a fluorescence microscope (C). Data represent mean of triplicates \pm SD of three independent experiments. $\left({ }^{*} p \leq 0.05\right.$, $* * \leq 0.0 \mathrm{I}, * * * \leq 0.00 \mathrm{I})$. 
Mannan pre-treatment without T. cruzi infection may increase nitrites concentrations because this polysaccharide also interacts with Toll-Like Receptor 4 (TLR4) [41]. Therefore, Man-BSA pre-treatment in T. cruzi infected cells was able to induce arginase activity and to reduce NO production in culture supernatants.

It has been reported that arginase induction has a detrimental role during several parasite infections by limiting classically activated Mo-dependent clearance and promoting parasite proliferation $[6,7,42]$. We have previously reported that $\mathrm{Cz}$ promotes $T$. cruzi intracellular growth in a similar way to IL-4 [16]. To investigate the role of arginase in parasite growth induced by Man-BSA, peritoneal cells were incubated with increased concentrations of mannan, $a M M$, Man-BSA or EDTA for $2 \mathrm{~h}$. After that, cells were infected by exposure to T. cruzi Tp for $24 \mathrm{~h}$ and then washed, fixed and stained. Intracellular amastigotes were counted at $72 \mathrm{~h}$ by immunofluorescence assays [17]. We only observed an increase in parasite number in Man-BSA-pre-treated Mo compared to untreated cells (Fig. 1C). Therefore, Man-BSA induced a shift in L-arginine metabolism that promotes parasite growth.
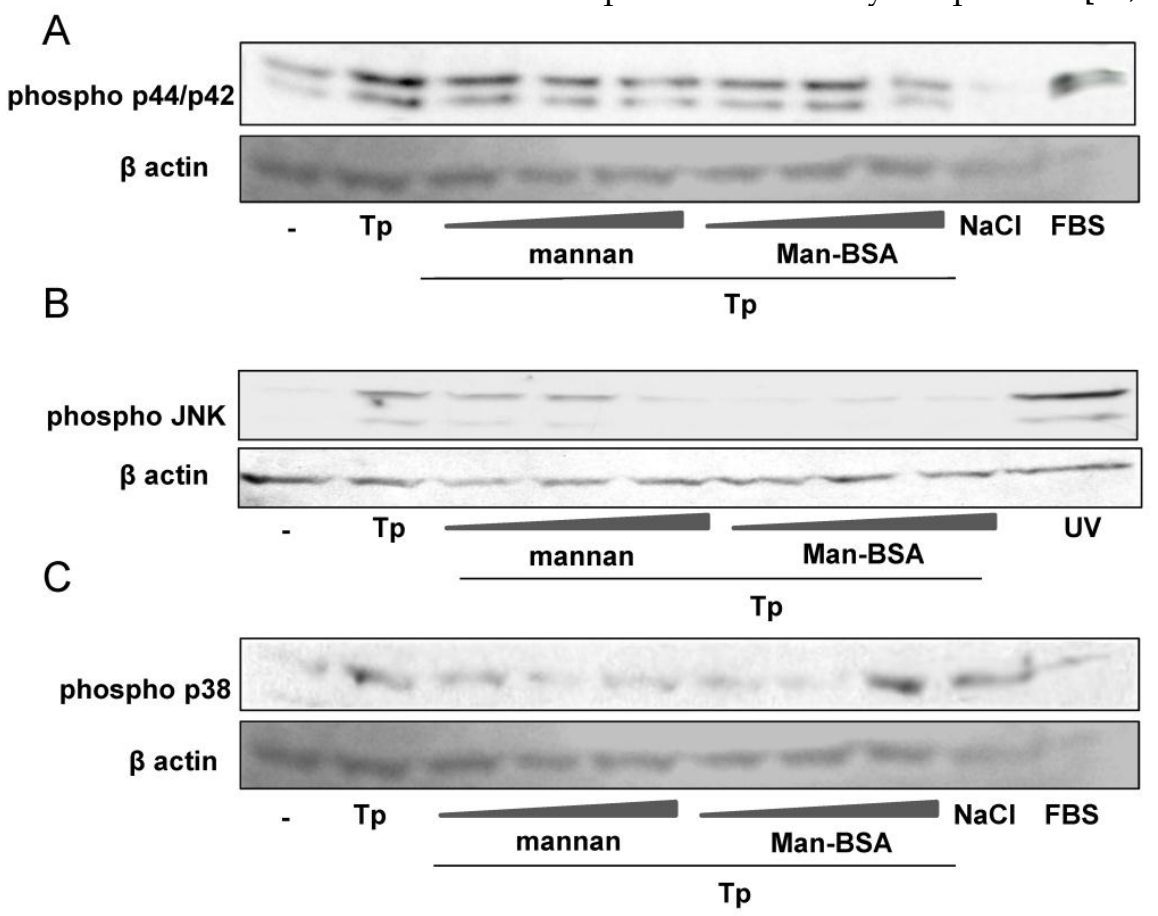

Figure 2. Man-BSA inhibits JNK and p44/p42 MAPK activation induced by $T$. cruzi. Peritoneal cells ( $2 \times 10^{6}$ cells/well) were cultured with Man-BSA (250, 500 and $\left.750 \mathrm{ng} / \mathrm{ml}\right)$, mannan $(2.5,5$ or $10 \mathrm{ug} / \mathrm{ml})$ or medium (-) for $2 \mathrm{~h}$ and then infected with Tp of $T$. cruzi (three parasite per cell) for $30 \mathrm{~min}$. Whole-cell lysates were resolved by SDS-PAGE (10\%), followed by Western blot using antibodies against phospho-JNK, phospho-p38, phospho-p44/p42 or $\beta$-actin. Peritoneal cells treated with FBS $(20 \%, 30 \mathrm{~min})$ were used as control for $\mathrm{p} 44 / \mathrm{p} 42$ phosphorylation $(\mathrm{A})$, UV-treated cells were used as control for JNK phosphorylation (B) and NaCl-treated cells $(300 \mathrm{mM}, 30 \mathrm{~min})$ were used as control for p38 MAPK phosphorylation (C)

\section{Man-BSA inhibits JNK and p44/p42 MAPK ac-}

We have previously demonstrated that $\mathrm{Cz}$ induced activation of p38 MAPK, while the parasite produced JNK and p44/p42 phosphorylation. Moreover, MAPK phosphorylation changed and JNK activation was blocked when Mo were pre-incubated with $\mathrm{Cz}$, before coming into contact with T. cruzi [17, 18].

Man-BSA pre-treatment was able to modified MAPK phosphorylation pattern induced by the parasite. To test that, peritoneal cells were incubated for $2 \mathrm{~h}$ in the presence of increasing concentrations of Man-BSA or mannan, and then infected with T. cruzi Tp. Man-BSA pre-treatment at the highest concentration markedly reduced $\mathrm{p} 44 / \mathrm{p} 42$ phosphorylation compared to non-treated infected cells (Fig. 2A). In addition, Man-BSA pre-treatment blocked JNK phosphorylation induced by the parasite (Fig. 2B). On the other hand, Man-BSA treatment at the highest concentration, increased p38 MAPK phosphorylation induced by the parasite (Fig. 2C). Therefore, similar to $\mathrm{Cz}$, Man-BSA is able to change MAPK phosphorylation profile induced by the parasite $[17,18]$.

In the present work, we evaluate whether

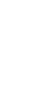




\section{Role of MR in Man-BSA-Mo and Cz-Mo inter- actions.}

We have showed that iNOS/arginase balance was biased towards arginase in Man-BSA pre-incubated T. cruzi infected Mo (Fig. 1A and 1B). Moreover, intracellular parasite growth was increased (Fig. 1C). In addition, the study of MAPK intracellular signals showed that pre-incubation with Man-BSA induced $\mathrm{p}-J \mathrm{NK}$ and $\mathrm{p}-\mathrm{p} 44 / \mathrm{p} 42$ down-regulation and p-p38 MAPK up-regulation in T. cruzi infected J774 cells (Fig. 2). These results are coincident with previous data published by our group $[17,18]$ and suggest that Man-BSA and Cz might interact with the same receptor. Moreover, Man-BSA pre-incubation may stimulate intracellular signals to induce $M R$ up-regulation or to increase MR recycling on Mo surface. To test this hypothesis we study by flow cytometry MR expression in Man-BSA or Cz treated cells. Peritoneal cells were incubated with FITC-Man-BSA at different time points-and then they were washed to remove unbound FITC-Man-BSA. IL-13 was used as a positive control in these experiments because it is known to up-regulate MR expression (Fig. 3A). Flow cytometry analysis showed that FITC-Man-BSA incubation increased the percentage of FITC + cells over the time. We obtained similar results using J774 cells (data not shown). To determine whether the increase in the percentage of FITC+ cells observed in Fig. 3A depends on the mannosylated portion, J774 cells where incubated with BSA or Man-BSA, for $2 \mathrm{~h}$ and then incubated with FITC-Man-BSA for 20 minutes. After that, cells were washed to remove unbound FITC-Man-BSA and they were analyzed by flow cytometry. We observed that Man-BSA but not BSA pre-incubation increased the percentage of FITC+ cells after FITC-Man-BSA incubation (Fig. 3B), confirming that the mannosylated fraction might determine an increase in MR expression or MR recycling. Subsequently, to evaluate whether $\mathrm{Cz}$ has a same effect on MR behavior, J774 cells were incubated with increasing concentrations of $\mathrm{Cz}$ during $2 \mathrm{~h}$ and then they were incubated with FITC-Man-BSA for 20 minutes. Flow cytometry analysis showed that $\mathrm{Cz}$ pre-treatment increased the percentage of FITC+ cells in a dose-dependent manner when compared with control cells (basal) (Fig. 3C). In addition, J774 cells incubated with increasing concentrations of mannan or BSA during $2 \mathrm{~h}$ and then incubated with FITC-Man-BSA for $20 \mathrm{~min}$, did not show difference in the percentage of FITC+ cells as compared to control cells (data not shown). In contrast, J774 cells incubated with increasing concentrations of Man-BSA augmented the percentage of FITC+ cells (data not shown). Therefore, this experiment may indicate that $\mathrm{Cz}$ and Man-BSA may induce an increase in MR expression or MR recycling.

\section{Man-BSA-Mo and Cz-Mo interactions in- creased $M R$ recycling.}

Next, we studied whether $\mathrm{Cz}$ or Man-BSA induced MR up-regulation or increased MR recycling. To test that, J774 cells were incubated for $3 \mathrm{~h}$ with FITC-Man-BSA at room temperature. After that, cells were washed with regular buffer or with acidic solution to remove FITC-Man-BSA from cell surface and then cells were fixed and analyzed by flow cytometry (Fig. 4A). We observed that acidic solution did not modify the percentage of FITC+ cells as compared with cells washed with regular buffer. This may indicate that FITC-Man-BSA could be endocyted. In addition, J774 cells were incubated with FITC-Man-BSA (Fig. 4B) or FITC-Cz (Fig. 4C) for 15, 60,120 or $180 \mathrm{~min}$ at room temperature or $180 \mathrm{~min}$ at 4 ${ }^{\circ} \mathrm{C}$. Then, cells were treated with regular buffer or with acidic solution and they were analyzed by confocal microscopy. This study showed that FITC-Man-BSA up-take increased over the time and it was not affected by acidic wash (Fig. 4B). In addition, FITC-Cz also increased inside cells; however it is slightly affected by acidic solution (Fig. 4C). On the other hand, incubation at low temperature blocked FITC-Man-BSA or FITC-Cz internalization (Fig. 4B and $4 \mathrm{C}$ ). Consequently, we have showed that MR expression on Mo may be constitutive with no significant changes upon its ligands contact. However, our results suggest that after Man-BSA or Cz contact, MR efficiently recycles on the cell surface.

\section{Cz-MR interaction on macrophages.}

To determine whether $\mathrm{Cz}$ could interact with $\mathrm{MR}$, we examined the ability of $\mathrm{Cz}$ to reduce FITC-anti-MR binding on Mo. To test that, peritoneal cells were incubated with $\mathrm{Cz}$, Man-BSA, BSA or medium (negative) for $30 \mathrm{~min}$ and then cells were washed and fixed. After that, cells were incubated with FITC-labeled anti-MR antibody for $30 \mathrm{~min}$ and analyzed by flow cytometry (Fig. 5). We observed that $\mathrm{Cz}$ or Man-BSA pre-incubation reduce FITC-anti-MR specific binding to MR. In contrast, no changes were observed when cells were incubated with BSA as a control. Consequently, this may indicate a direct interaction of $\mathrm{Cz}$ with MR on peritoneal Mo surface. 

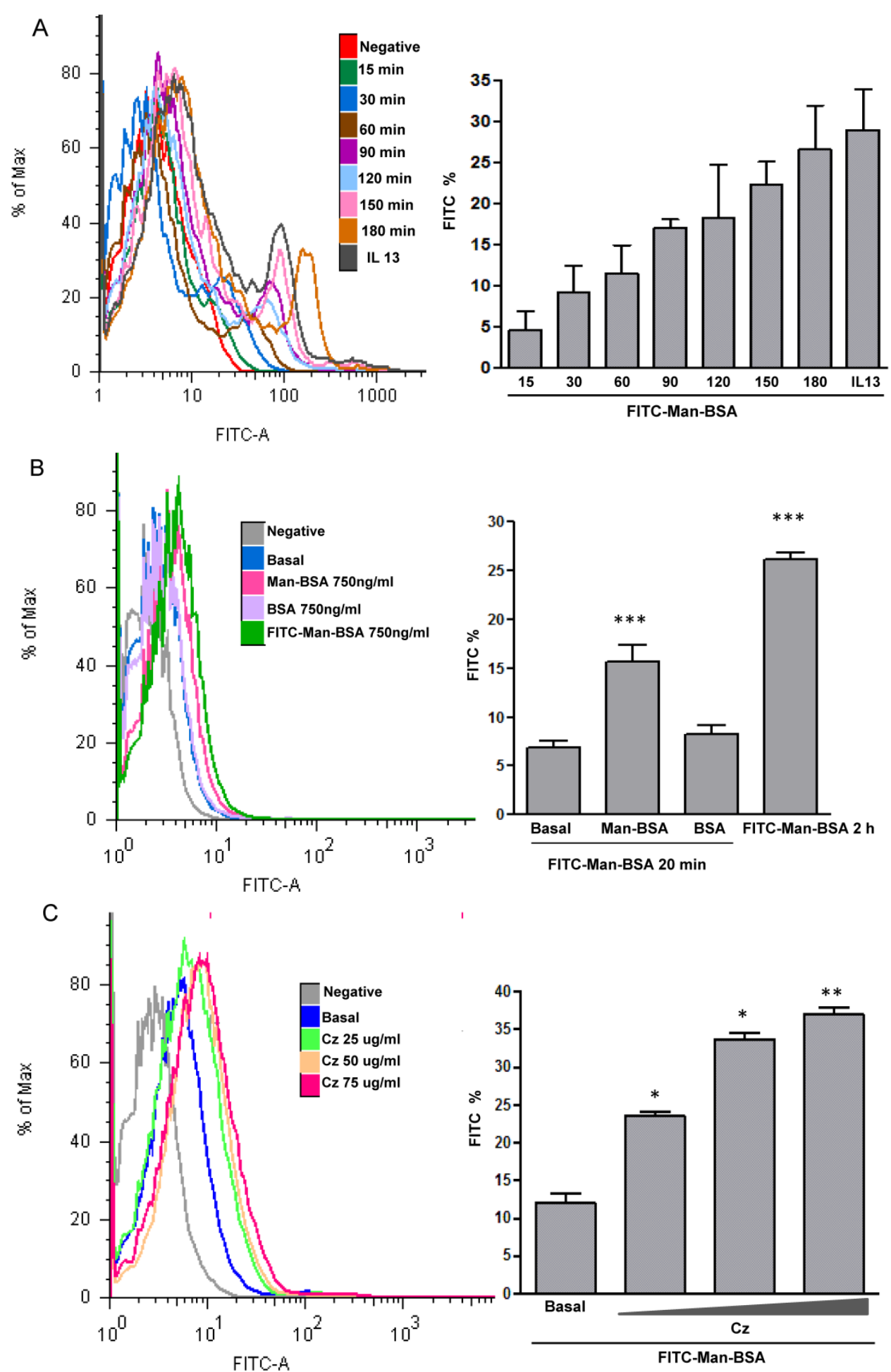

Figure 3. Role of MR in the interaction between Man-BSA and Cz with Mo. Peritoneal cells ( $1 \times 10^{6}$ cells/well) were incubated for 15, 30, 60, 90, 120, 150 and $180 \mathrm{~min}$ with FITC-Man-BSA $(500 \mathrm{ng} / \mathrm{ml})$ or IL-13 for $180 \mathrm{~min}$ at room temperature. Then, cells were washed for removing unbound FITC-Man-BSA and fixed (A). J774 cells ( $1 \times 10^{6} \mathrm{cells} /$ well) were treated with Man-BSA $(750 \mathrm{ng} / \mathrm{ml})$, BSA $(750 \mathrm{ng} / \mathrm{ml})$, FITC-Man-BSA $(750 \mathrm{ng} / \mathrm{ml})$ or left it untreated (basal) during $2 \mathrm{~h}$. Then, cells treated with Man-BSA, BSA and basal cells were incubated with FITC-Man-BSA $(500 \mathrm{ng} / \mathrm{ml})$ for 20 minutes. After that, cells were washed to remove unbound FITC-Man-BSA and fixed (B). $J 774$ cells $\left(I \times 10^{6}\right.$ cells/well) were treated with $\mathrm{Cz}(25,50$ or $75 \mathrm{ug} / \mathrm{ml}$ ) during $2 \mathrm{~h}$ or left it untreated (basal) and then incubated with FITC-Man-BSA (500 $\mathrm{ng} / \mathrm{ml}$ ) for 20 minutes. Then, cells were washed to remove unbound FITC-Man-BSA and fixed (C). FITC+ cells were analyzed by flow cytometry. Bars represent the mean $\pm S D$. Data are representative of three independent experiments. 

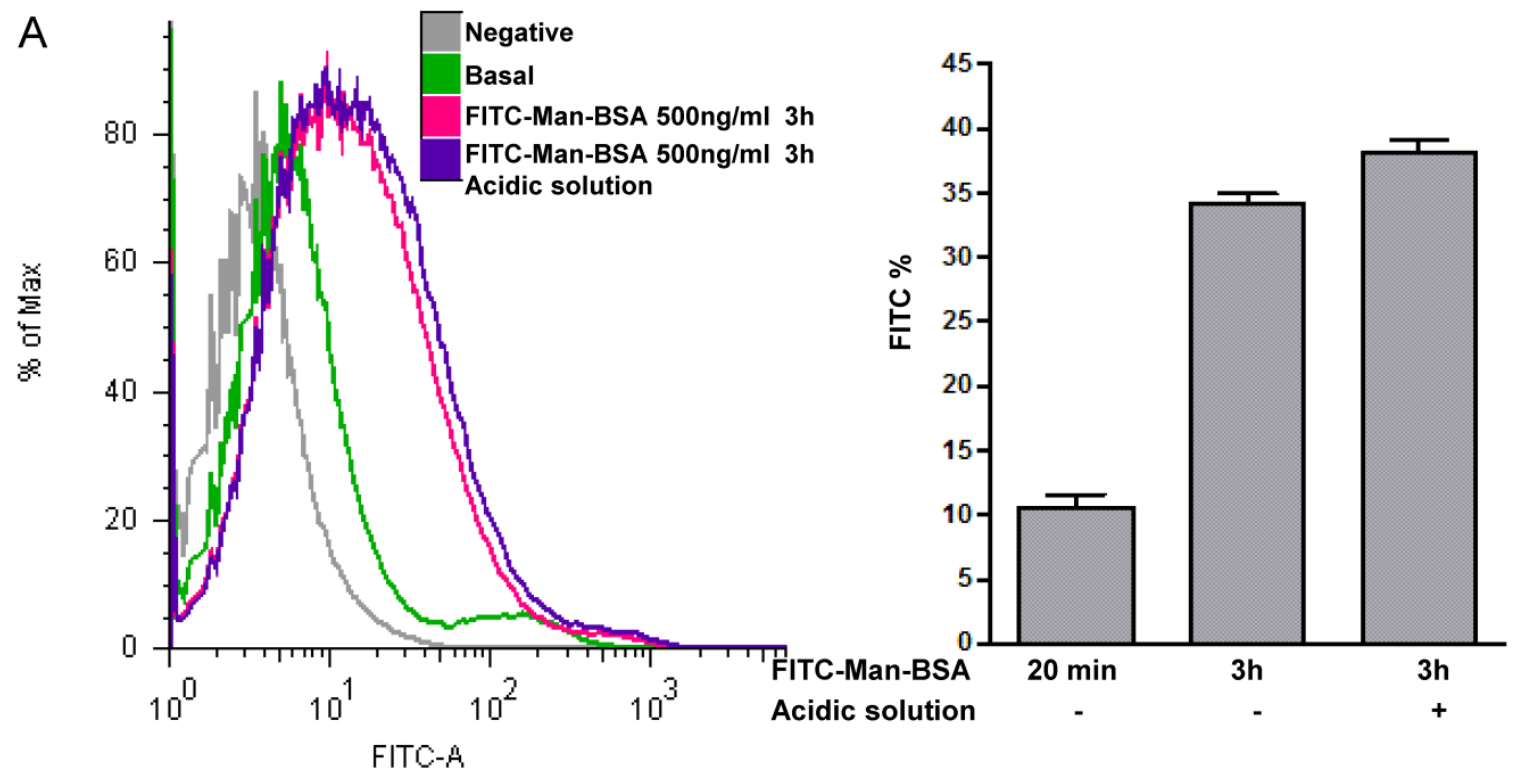

B FITC-Man-BSA RT
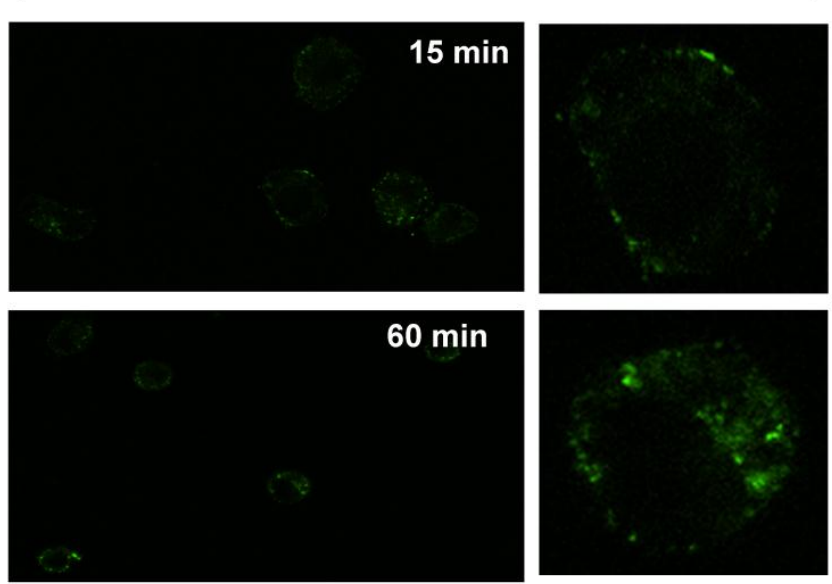

FITC-Man-BSA RT Acidic wash
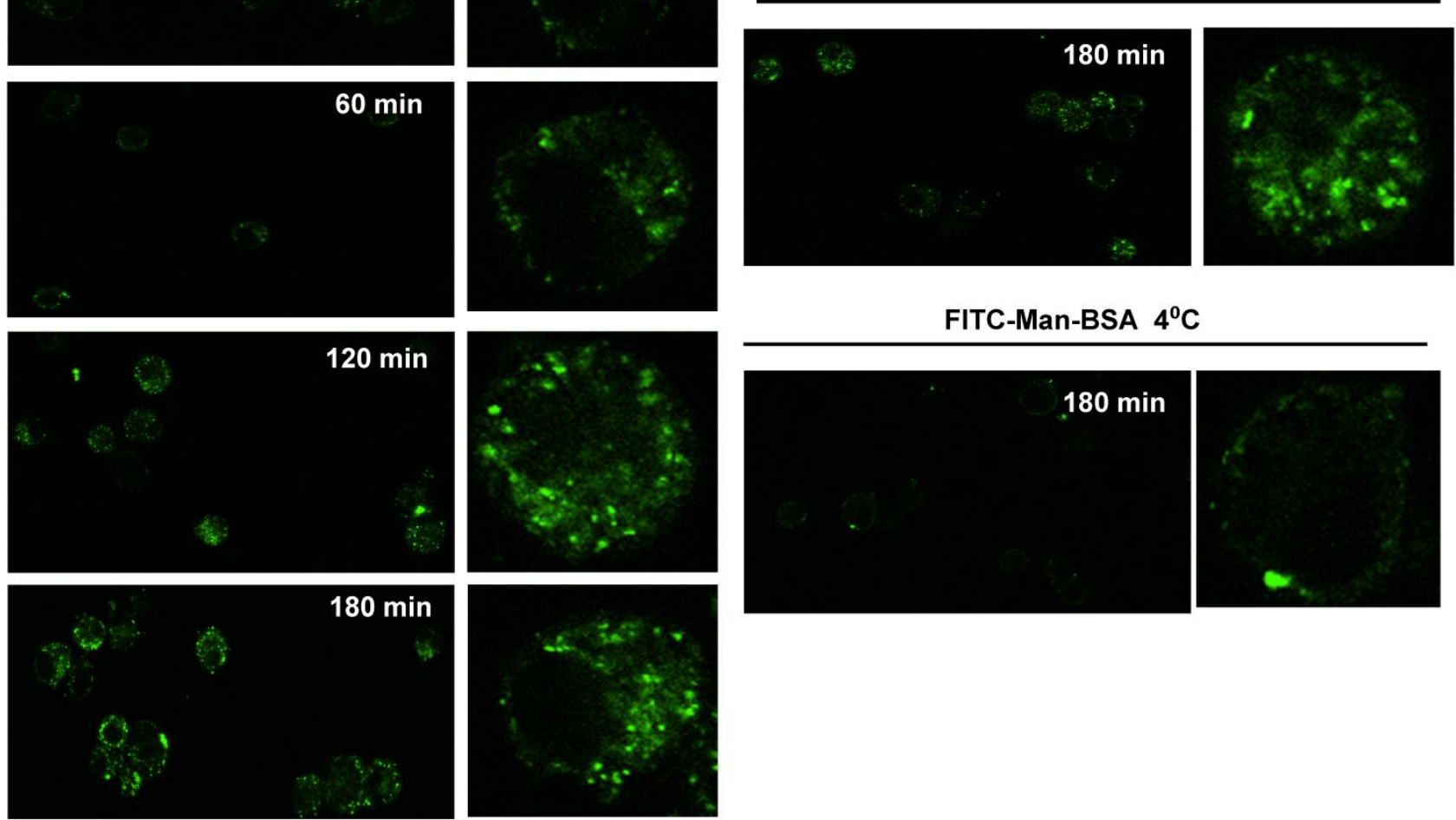

FITC-Man-BSA $4^{\circ} \mathrm{C}$

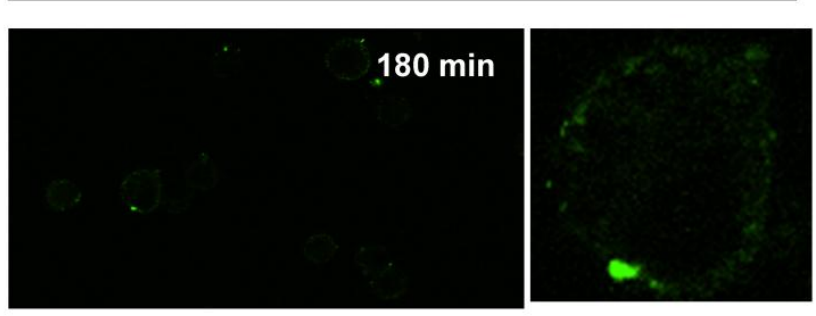


C FITC-Cz RT
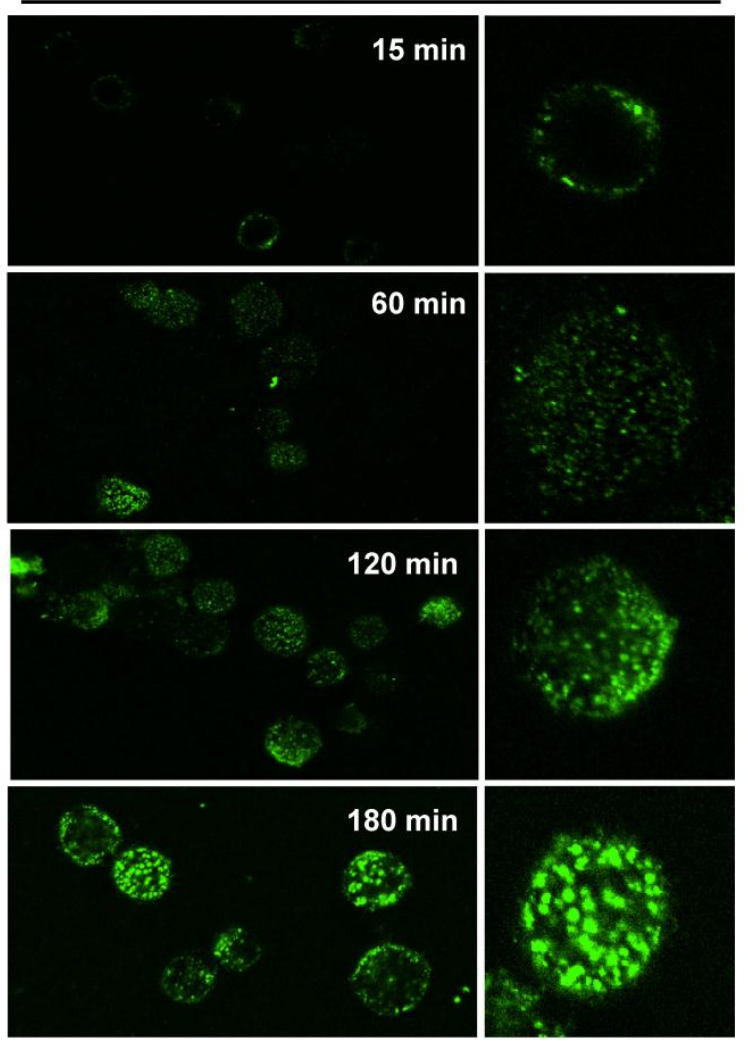

FITC-Cz RT Acidic wash

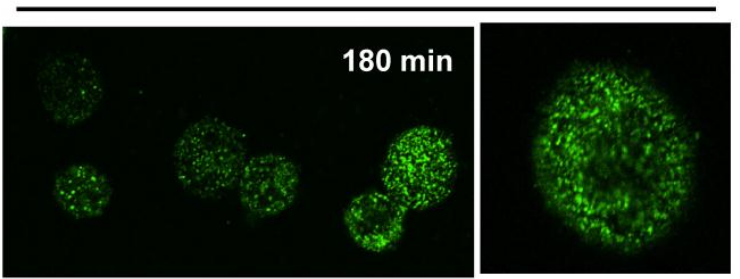

FITC-Cz $4^{\circ} \mathrm{C}$

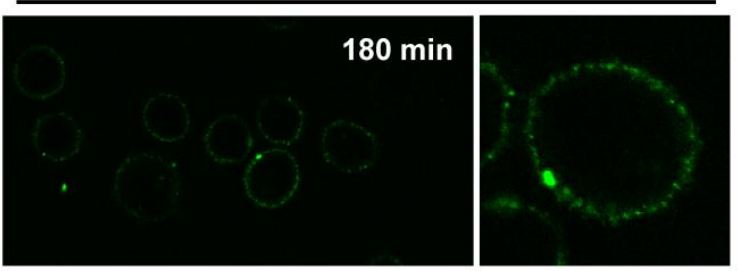

Figure 4. Increased MR recycling induced by Man-BSA and Cz contact with Mo. J774 cells (IxI06cells/well) were incubated with FITC-Man-BSA $(500 \mathrm{ng} / \mathrm{ml})$ for $20 \mathrm{~min}$ (basal) or $3 \mathrm{~h}$. After incubation, cells were washed with regular buffer or with acidic solution and they were analyzed by flow cytometry. Bars represent the mean \pm SD. Data are representative of three independent experiments (A). J774 cells (IxI $0^{6}$ cell/well) were incubated for I5, 60, I20 and I80 min with FITC-Man-BSA (500ng/ml) (B) or FITC-Cz $(50 \mathrm{ug} / \mathrm{ml})(\mathrm{C})$ at room temperature (RT) or $4^{\circ} \mathrm{C}$ (I80 min). Then, cells were washed with regular buffer or with acidic solution and they were analyzed by confocal microscopy. Cells were observed at a 40x magnification. A representative field for each group is shown. Magnified image of the cells is shown in right box.
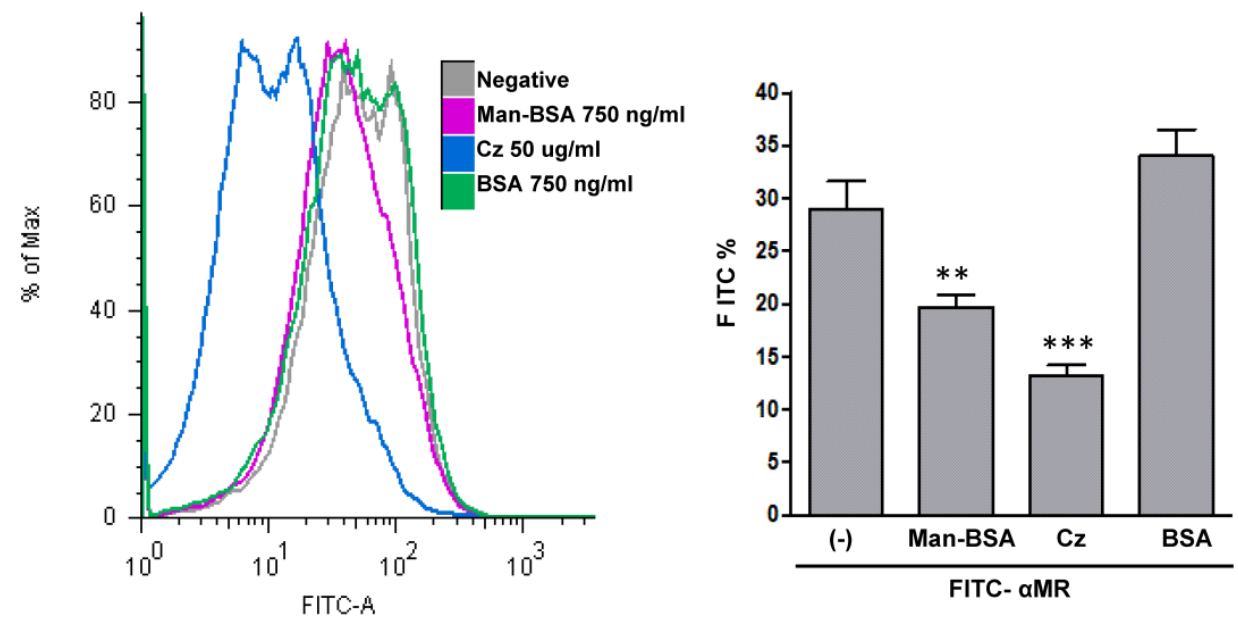

Figure 5. Cz-MR interaction on Mo. Peritoneal cells from BALB/c mice were incubated for $30 \mathrm{~min} \mathrm{with} \mathrm{Cz}(50 \mathrm{ug} / \mathrm{ml})$, Man-BSA $(750 \mathrm{ng} / \mathrm{ml})$, BSA $(750 \mathrm{ng} / \mathrm{ml})$ or medium $(-)$. Then, cells were washed, fixed and incubated for 30 min with FITC-labeled anti-MR antibody (I Oug/ml). FITC+ cells were analyzed by flow cytometry. The bars represent the mean \pm SD. Data are representative of three independent experiments. 


\section{MR expression in F4/80+ cells from T. cruzi in- fected mice.}

We have indirectly determined, through Man-BSA interaction, that MR plays an important role in arginase induction and in parasite growth in vitro. In addition, we have showed that arginase expression and activity is up-regulated in Mo from infected mice at 15-19 days post infection (d.p.i) (Stempin et al. unpublished data) and these results are coincident with parasitemia peak [43]. Therefore, we evaluated if MR was up regulated on Mo of T. cruzi infected
BALB/c mice. To test that, peritoneal cells from $T$. cruzi infected BALB/c mice were removed at 13 and 15 d.p.i. Peritoneal cells were incubated with FITC-Man-BSA and PE-labeled anti-mouse F4/80 antibody. After $20 \mathrm{~min}$, cells were washed and the number of $\mathrm{F} 4 / 80^{+} \mathrm{MR}^{+}$double positive cells was analyzed by flow cytometry. As Fig. 6 shows, we observed an increase in $\mathrm{F} 4 / 80^{+} \mathrm{MR}^{+}$double positive cells along as the infection progress as compared with control non-infected cells. Therefore, MR may play an important role in vivo during T. cruzi infection.
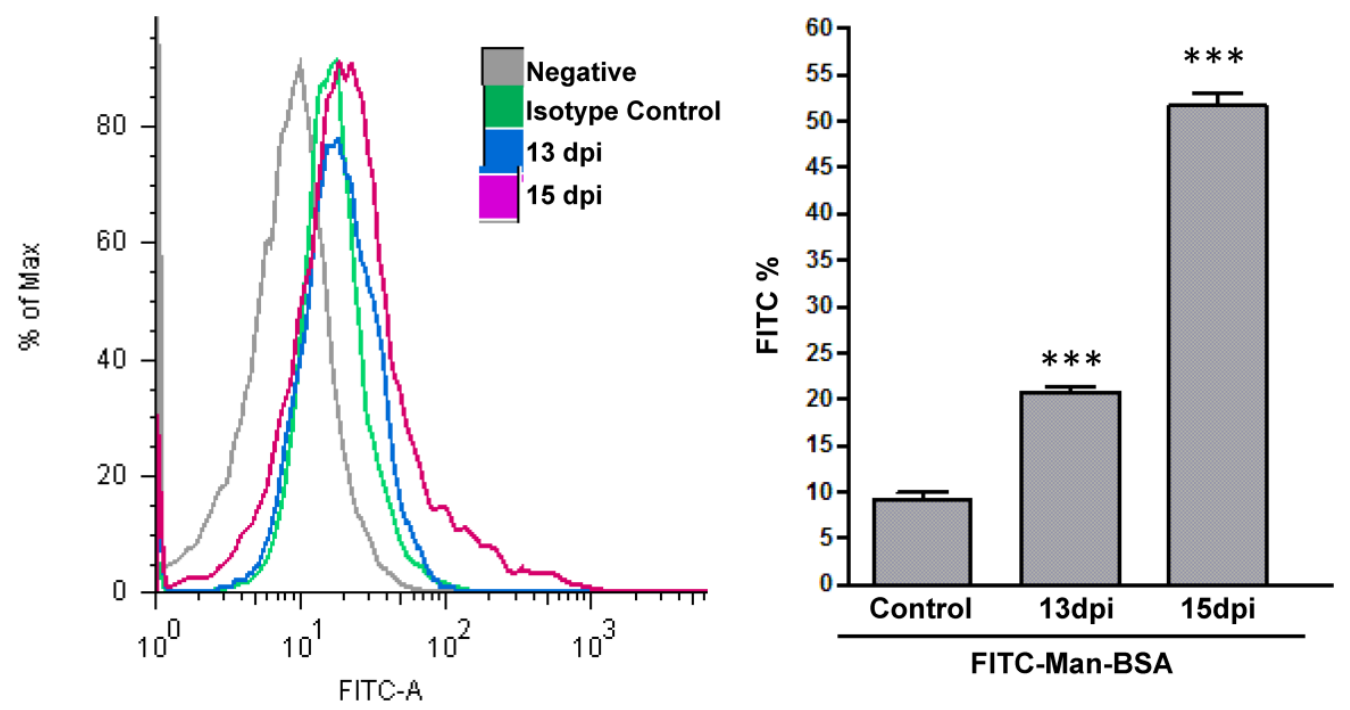

Figure 6. MR expression in F4/80+ cells from T. cruzi infected mice. Peritoneal cells from T. cruzi infected mice were removed at 13 and 15 days post infection. Peritoneal cells were incubated with FITC-labeled Man-BSA and PE-labeled anti-mouse F4/80 antibody. After $20 \mathrm{~min}$, cells were washed and the number of F4/80+ and Man-BSA+ cells were analyzed by flow cytometry. Peritoneal cells from non-infected mice (control) were incubated with FITC-labeled Man-BSA and PE-labeled anti-mouse F4/80 antibody for 20 min. Bars represent mean \pm SD. Data are representative of three independent assays.

\section{MR blockade decreased arginase activity and parasite growth in $T$. cruzi-infected macro- phages.}

We have demonstrated that Cz-Mo and Man-BSA-Mo interactions could influence T. cruzi growth through the induction of a preferential metabolic pathway by modulating the intracellular signals that regulate L-arginine metabolism (Fig. 1 and 2). In addition, we saw an increase in $\mathrm{F} 4 / 80^{+} \mathrm{MR}^{+}$double positive cells during T. cruzi infection (Fig. 6). Therefore, we decided to investigate MR relevance in $T$. cruzi infection by blocking MR in peritoneal cells cultures infected in vitro. To do that, peritoneal cells were incubated for $2 \mathrm{~h}$ with anti-MR or control IgG and then treated cells were infected with T. cruzi Tp (three parasites per cell). After $24 \mathrm{~h}$, cells were washed to remove non-internalized parasites. Arginase activity was measured (Fig. 7A) and intracellular amastigote number was determined by immunofluorescence [18] $72 \mathrm{~h}$ later (Fig. 7B). We observed a reduction in arginase activity in anti-MR antibody pre-incubated infected cells as compared with control cells (Fig. 7A). Moreover, the amastigote number was reduced in anti-MR pre-treated cells (Fig. 7B and 7C). These data were corroborated using J774 cells (data not shown). Therefore, MR may facilitate T. cruzi growth within Mo through the induction of arginase activity. 

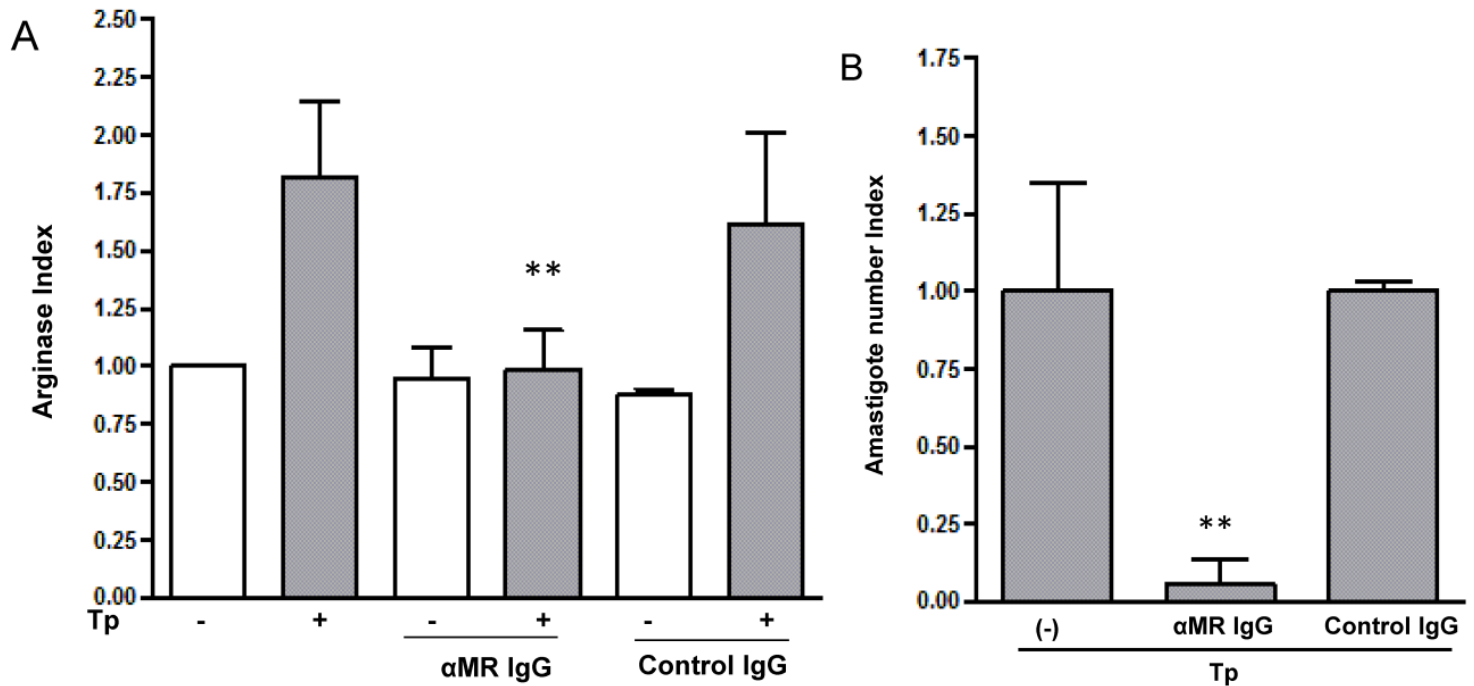

C

$100 x$

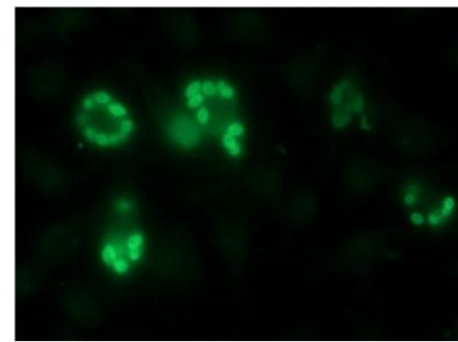

Untreated

aMR IgG
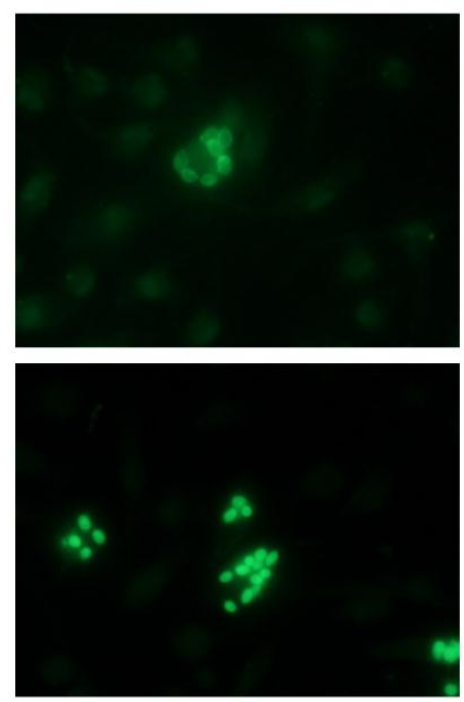

$40 X$
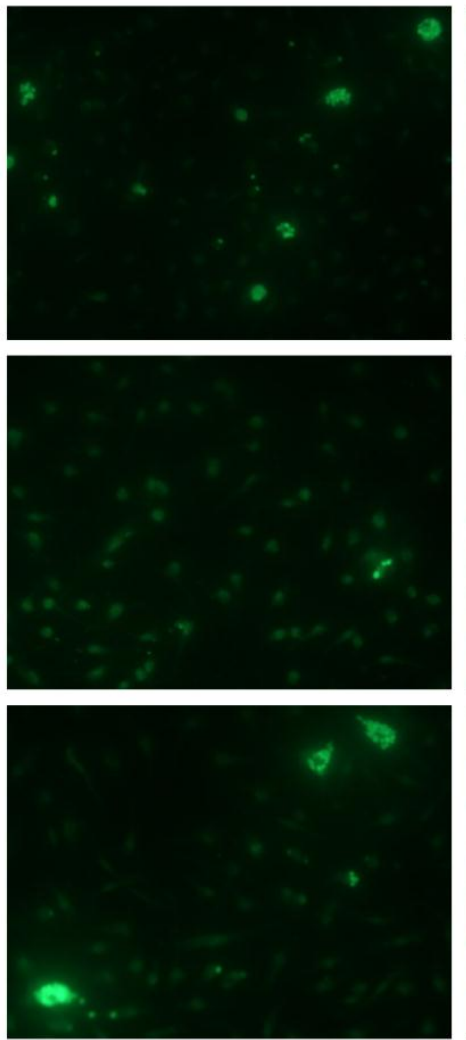

$20 x$
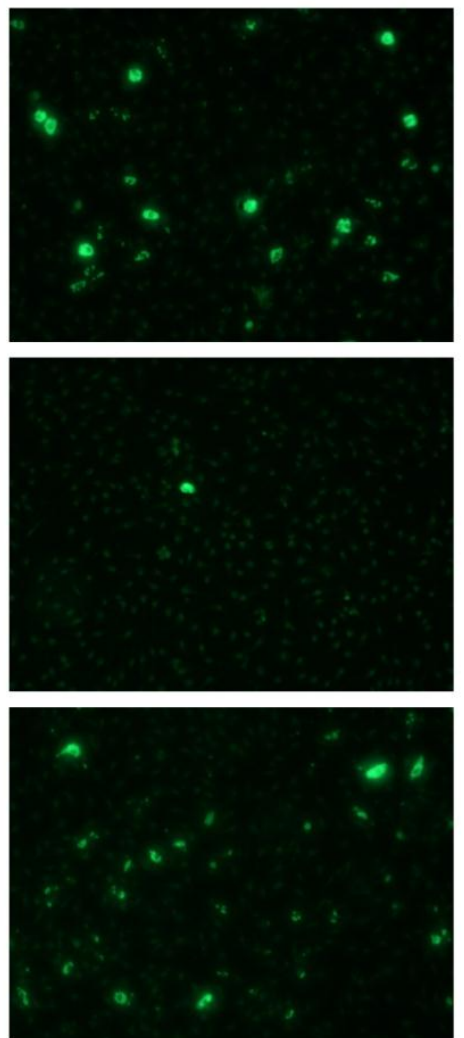

Figure 7. MR blockade in in vitro T. cruzi-infected macrophages decreased arginase activity and parasite growth. Peritoneal cells $\left(5 \times 10^{5}\right.$ cells/well) were incubated for $2 \mathrm{~h}$ with anti-MR IgG or control lgG. Treated cells were then infected with $T$. cruzi Tp (three parasites per cell). After $24 \mathrm{~h}$, cells were washed to remove non-internalized parasites and 72 $\mathrm{h}$ later arginase activity was determined in cells lysates (A). Peritoneal cells $\left(5 \times 10^{5}\right.$ cells/well) were plated on $12-\mathrm{mm}$ round-glass coverslips and incubated for $2 \mathrm{~h}$ with anti-MR $\lg$ G or control lgG. Treated cells were infected with $T$. cruzi $T p$ (three parasites per cell). After $24 \mathrm{~h}$, cells were washed to remove non-internalized parasites and the number of amastigotes $/ 100$ cells was counted $72 \mathrm{~h}$ later by immunofluorescence. Bars represent mean of triplicates $\pm \mathrm{SD}$ of three independent experiments (B). Cells were observed at 100x, 40x and 20x magnification. A representative field for each group is shown (C). 


\section{Discussion}

Mo activation by T helper type 1 (Th1) cytokines or bacterial products such as lipopolysaccharide or CpG DNA, induces NO production that provides a key defensive element in various infectious diseases. On the other hand, Mo differentiated in the presence of Th2 cytokines have enhanced capacity for endocytosis but do not exert enhanced killing functions towards microbes $[6,7,44]$. Furthermore, NO production is counteracted by the expression of arginase-1, an enzyme that competes with iNOS for L-arginine, leading to the production of L-ornithine and urea $[8$, $45,46]$. We have previously demonstrated that $\mathrm{Cz}$ induced alternatively activated Mo [16, 47]. Cz-stimulated Mo exhibit increased arginase- 1 activity and expression, and secrete IL-10 and TGF- $\beta$ [16, 17]. Moreover, Cz-activated Mo favors T. cruzi growth [16] and arginase- 1 inhibition leads to a drastic reduction in T. cruzi replication in Mo [18]. In addition, we showed that mice immunization with the immune dominant antigen $\mathrm{Cz}$ results in high Th2 cytokine secretion (IL- 4, IL-5, IL-10), and marginal levels of IFN- $\gamma$ and IL-12 [47].

One of the hallmarks of alternatively activated Mo is the increased expression of the MR [6, 23]. This receptor is a C-type lectin primarily expressed on Mo and DC. Its three distinct extracellular binding sites recognize a wide range of both endogenous and exogenous ligands, therefore MR has been implicated in homeostatic processes and in pathogen recognition. In order to study possible receptors involved in arginase induction we perform experiments using different MR ligands. Surprisingly, our results demonstrated that Man-BSA pre-incubation, but not mannan or aMM, modifies iNOS/arginase balance. Moreover, this result is in accordance to Chieppa et al. [48]. The authors showed that not all MR ligands had the same functional effects on cells. While mannan had no significant effect on cytokine production, mannose-capped LAM (Man-LAM) significantly increased IL-10 and decreased IL-12 production in LPS-maturing DC. In addition, Liempt et al. demonstrated that schistosome soluble egg antigens (SEA) internalization through C-type lectins (DC-SIGN, MGL and MR) on DC, induced DC activation and subsequent production of cytokines contributing the Th1/Th2 balance [49]. Our results suggest that the specific MR-ligand Man-BSA shifted iNOS/arginase balance towards arginase promoting $T$. cruzi intracellular growth. Therefore, Man-BSA is able to induce on Mo a similar profile to the one observed in Cz-treated Mo [16]. Then, this work is the first to identify a specific MR ligand able to trigger arginase activity. Our results also suggest that $\mathrm{Cz}$ may mediate its effect by the interaction with MR, since it is able to reduce anti-MR binding on Mo.

On the other hand, parasites are not only able to successfully reside in Mo, but are also capable to modify signaling cascades from these cells in order to overcome different immune defense mechanisms. To explore whether different signalling pathways are involved in iNOS/arginase balance bias we studied MAPK activation. We observed that Man-BSA pre-treatment reduces $\mathrm{p} 44 / \mathrm{p} 42$ MAPK phosphorylation and blocks JNK phosphorylation induced by $T$. cruzi. In contrast, Man-BSA pre-treatment increased p38 MAPK phosphorylation induced by the parasite. Therefore, we demonstrated that Man-BSA modifies MAPK phosphorylation pattern in cells that had been stimulated by the parasite.

In agreement with our results, MR was shown to participate in intracellular signalling leading to target gene expression [33, 48, 50-55]. Intracellular targeting is mediated by a tyrosine-based motif in the cytoplasmic tail [29]. It appears to require the assistance from other receptors in order to trigger any signalling cascade which is also consistent with the lack of signalling motifs in its cytoplasmic domain [56]. For instance, Da Silva et al. [57] demonstrated that MR is a size dependent co-receptor for dectin-1 that participates in the stimulation of TNF and inhibition of IL-10 by small chitin, an abundant polysaccharide in nature. Additionally, Zhang et al. revealed the participation of MR in NF-kB-mediated gene expression in response to $P$. carinii in alveolar Mo [54]. In other work, the authors demonstrated that $P$. carinii induced MR and TLR2 interaction, which indicates that MR, after binding with the pathogen, might form a functional complex with TLR2 and facilitate signal transduction [51]. Consequently, our results demonstrated that MR could be involved in an additional mechanism during T. cruzi infection. We have observed MR expression increased in F4/80+ cells at 13 and 15 d.p.i. Therefore, $\mathrm{Cz}$, liberated by the immune defense reaction, may bind to MR providing a new environment that promote T. cruzi growth.

On the other hand, MR constitutively recycles between the plasma membrane and the early endosomal compartment, even in the absence of any ligand. At the steady state $10-30 \%$ of the receptor is found at the cell surface and the remaining $70 \%$ is localized intracellularly [58]. In our system, MR-ligand Man-BSA as well as T. cruzi antigen Cz favour MR recycling since acidic washes did not affect MR behavior. These results are in accordance to Beharka et al. where they demonstrated that surfactant protein A (SP-A) binds to MR on alveolar Mo and 
induces the activation of a signal transduction pathway(s) leading to the increased in MR trafficking to the plasma membrane [55].

Thus, we postulate that during T. cruzi infection, $\mathrm{Cz}$ may contact with MR up-regulating arginase activity and promoting the intracellular growth of parasites. Then, the parasite might enhance MR recycling.

Furthermore, MR is expressed on F4/80+ peritoneal cells of $T$. cruzi infected mice at 13 and 15 days post infection coincident with parasitemia peak and arginase up-regulation [43] indicating that $M R$ is up-regulated during T. cruzi infection. Moreover, when we investigated the effect of MR blocking antibody in T. cruzi infected peritoneal Mo, we clearly observed that arginase activity and intracellular parasite growth decreased. This work confirms that the ligation of MR on Mo might be an interesting evasion mechanism of the innate immune response used by $T$. cruzi to favor its installation in the host $[59,60]$. Besides, MR is important for pathogens entry into Mo [61, 62]. However, MR function in host defense is not yet clearly understood since it was demonstrated that MR is not essential for host defense against some parasite infections in MR-deficient mice [62,63]. Even though, pathogen recognition through MR does not appear to enhance susceptibility of MR-deficient animals to infection, the identification of parasite components that bound to MR and induce arginase could represent a new field of investigations on Mo-T. cruzi interaction.

On the other hand, the molecular mechanisms underlying the host-parasite interactions are still waiting to be discovered. Taken together, this work contributes to the knowledge of new factors that induce arginase, as well as the membrane receptors and signaling involved. It would make it possible to better identify the optimal targets to inhibit the arginase pathway to control survival of T. cruzi in Mo.

\section{Acknowledgements}

This work was supported by Consejo Nacional de Investigaciones Científicas y Tecnológicas (CONICET), Secretaria de Ciencia y Tecnología de la Universidad Nacional de Córdoba (Secyt-UNC), Ministerio de Ciencia y Tecnología de Córdoba (MinCyT-Cba) and Agencia Nacional de Promoción Científica y Tecnológica (ANPCyT). F.M.C. is a permanent research fellow of CONICET. C.C.S., L.R.D and V.V.G. thank CONICET for their fellowship grants. We thank Lorena Guasconi for the support in MR blockade assays and Javier Jaldin-Fincati for the support in MR recycling experiments.

\section{Conflict of Interests}

The authors have declared that no conflict of interest exists.

\section{References}

1. Tanowitz HB, Kirchhoff LV, Simon D, Morris SA, Weiss LM, Wittner M. Chagas' disease. Clin Microbiol Rev 1992;5:400-19.

2. Seljelid R, Eskeland T. The biology of macrophages: I. General principles and properties. Eur J Haematol 1993;51:267-75.

3. Seljelid R, Busund LT. The biology of macrophages: II. Inflammation and tumors. Eur J Haematol 1994;52:1-12.

4. Ehlers MR, Daffe M. Interactions between Mycobacterium tuberculosis and host cells: are mycobacterial sugars the key? Trends Microbiol 1998;6:328-35.

5. Falkow S, Isberg RR, Portnoy DA. The interaction of bacteria with mammalian cells. Annu Rev Cell Biol 1992;8:333-63.

6. Gordon S. Alternative activation of macrophages. Nat Rev Immunol 2003;3:23-35.

7. Mosser DM. The many faces of macrophage activation. J Leukoc Biol 2003;73:209-12.

8. Munder M, Eichmann K, Modolell M. Alternative metabolic states in murine macrophages reflected by the nitric oxide synthase/arginase balance: competitive regulation by $\mathrm{CD} 4+\mathrm{T}$ cells correlates with Th1/Th2 phenotype. J Immunol 1998;160:5347-54

9. Scharfstein J, Schechter M, Senna M, Peralta JM, Mendonca-Previato L, Miles MA. Trypanosoma cruzi: characterization and isolation of a 57/51,000 m.w. surface glycoprotein (GP57/51) expressed by epimastigotes and bloodstream trypomastigotes. J Immunol 1986;137:1336-41.

10. Parodi AJ, Labriola C, Cazzulo JJ. The presence of complex-type oligosaccharides at the C-terminal domain glycosylation site of some molecules of cruzipain. Mol Biochem Parasitol 1995;69:247-55.

11. Eakin AE, Mills AA, Harth G, McKerrow JH, Craik CS. The sequence, organization, and expression of the major cysteine protease (cruzain) from Trypanosoma cruzi. J Biol Chem 1992;267:7411-20.

12. Martinez J, Campetella O, Frasch AC, Cazzulo JJ. The major cysteine proteinase (cruzipain) from Trypanosoma cruzi is antigenic in human infections. Infect Immun 1991;59:4275-7.

13. Cazzulo JJ, Stoka V, Turk V. Cruzipain, the major cysteine proteinase from the protozoan parasite Trypanosoma cruzi. Biol Chem 1997;378:1-10.

14. Arnholdt AC, Piuvezam MR, Russo DM, Lima AP, Pedrosa RC, Reed SG, Sharfstein J. Analysis and partial epitope mapping of human $\mathrm{T}$ cell responses to Trypanosoma cruzi cysteinyl proteinase. J Immunol 1993;151:3171-9.

15. Laderach D, Cerban F, Motran C, Vottero de CE, Gea S. Trypanosoma cruzi: the major cysteinyl proteinase (cruzipain) is a relevant immunogen of parasite acidic antigens (FIII). Int J Parasitol 1996;26:1249-54

16. Stempin C, Giordanengo L, Gea S, Cerban F. Alternative activation and increase of Trypanosoma cruzi survival in murine macrophages stimulated by cruzipain, a parasite antigen. J Leukoc Biol 2002;72:727-34.

17. Stempin CC, Tanos TB, Coso OA, Cerban FM. Arginase induction promotes Trypanosoma cruzi intracellular replication in Cruzipain-treated J774 cells through the activation of multiple signaling pathways. Eur J Immunol 2004;34:200-9.

18. Stempin CC, Garrido VV, Dulgerian LR, Cerban FM. Cruzipain and SP600125 induce p38 activation, alter NO/arginase balance and favor the survival of Trypanosoma cruzi in macrophages. Acta Trop 2008;106:119-27. 
19. Stahl PD, Ezekowitz RA. The mannose receptor is a pattern recognition receptor involved in host defense. Curr Opin Immunol 1998;10:50-5.

20. Linehan SA, Martinez-Pomares L, Gordon S. Mannose receptor and scavenger receptor: two macrophage pattern recognition receptors with diverse functions in tissue homeostasis and host defense. Adv Exp Med Biol 2000;479:1-14.

21. Taylor ME. Structure and function of the macrophage mannose receptor. Results Probl Cell Differ 2001;33:105-21.

22. East L, Isacke CM. The mannose receptor family. Biochim Biophys Acta 2002;1572:364-86.

23. Stein M, Keshav S, Harris N, Gordon S. Interleukin 4 potently enhances murine macrophage mannose receptor activity: a marker of alternative immunologic macrophage activation. J Exp Med 1992;176:287-92.

24. Mokoena T, Gordon S. Human macrophage activation. Modulation of mannosyl, fucosyl receptor activity in vitro by lymphokines, gamma and alpha interferons, and dexamethasone. J Clin Invest 1985;75:624-31.

25. Martinez-Pomares L, Wienke D, Stillion R, McKenzie EJ, Arnold JN, Harris J, McGreal E, Sim RB, Isacke CM, Gordon S. Carbohydrate-independent recognition of collagens by the macrophage mannose receptor. Eur J Immunol 2006;36:1074-82.

26. Wileman T, Boshans RL, Schlesinger P, Stahl P. Monensin inhibits recycling of macrophage mannose-glycoprotein receptors and ligand delivery to lysosomes. Biochem J 1984;220:665-75.

27. Wileman T, Boshans R, Stahl P. Uptake and transport of mannosylated ligands by alveolar macrophages. Studies on ATP-dependent receptor-ligand dissociation. J Biol Chem 1985;260:7387-93.

28. Tietze C, Schlesinger P, Stahl P. Mannose-specific endocytosis receptor of alveolar macrophages: demonstration of two functionally distinct intracellular pools of receptor and their roles in receptor recycling. J Cell Biol 1982;92:417-24.

29. Taylor PR, Gordon S, Martinez-Pomares L. The mannose receptor: linking homeostasis and immunity through sugar recognition. Trends Immunol 2005;26:104-10.

30. Lefkowitz DL, Lincoln JA, Lefkowitz SS, Bollen A, Moguilevsky $\mathrm{N}$. Enhancement of macrophage-mediated bactericidal activity by macrophage-mannose receptor-ligand interaction. Immunol Cell Biol 1997;75:136-41.

31. Murray HW. Effect of continuous administration of interferon-gamma in experimental visceral leishmaniasis. J Infect Dis 1990;161:992-4.

32. Roach TI, Kiderlen AF, Blackwell JM. Role of inorganic nitrogen oxides and tumor necrosis factor alpha in killing Leishmania donovani amastigotes in gamma interferon-lipopolysaccharide-activated macrophages from Lshs and Lshr congenic mouse strains. Infect Immun 1991;59:3935-44.

33. Yamamoto $Y$, Klein TW, Friedman H. Involvement of mannose receptor in cytokine interleukin-1beta (IL-1beta), IL-6, and granulocyte-macrophage colony-stimulating factor responses, but not in chemokine macrophage inflammatory protein 1beta (MIP-1beta), MIP-2, and KC responses, caused by attachment of Candida albicans to macrophages. Infect Immun 1997;65:1077-82.

34. Garner RE, Rubanowice K, Sawyer RT, Hudson JA. Secretion of TNF-alpha by alveolar macrophages in response to Candida albicans mannan. J Leukoc Biol 1994;55:161-8.

35. Shibata Y, Metzger WJ, Myrvik QN. Chitin particle-induced cell-mediated immunity is inhibited by soluble mannan: mannose receptor-mediated phagocytosis initiates IL-12 production. J Immunol 1997;159:2462-7.

36. Prigozy TI, Sieling PA, Clemens D, Stewart PL, Behar SM, Porcelli SA, Brenner MB, Modlin RL, Kronenberg M. The mannose receptor delivers lipoglycan antigens to endosomes for presentation to $\mathrm{T}$ cells by $\mathrm{CD} 1 \mathrm{~b}$ molecules. Immunity 1997;6:187-97.

37. Labriola C, Sousa M, Cazzulo JJ. Purification of the major cysteine proteinase (cruzipain) from Trypanosoma cruzi by affinity chromatography. Biol Res 1993;26:101-7.

38. Giordanengo L, Fretes R, Diaz H, Cano R, Bacile A, Vottero-Cima E, Gea S. Cruzipain induces autoimmune response against skeletal muscle and tissue damage in mice. Muscle Nerve 2000;23:1407-13.

39. Corraliza IM, Campo ML, Soler G, Modolell M. Determination of arginase activity in macrophages: a micromethod. J Immunol Methods 1994;174:231-5.

40. Green LC, Wagner DA, Glogowski J, Skipper PL, Wishnok JS, Tannenbaum SR. Analysis of nitrate, nitrite, and [15N]nitrate in biological fluids. Anal Biochem 1982;126:131-8.

41. Dostert C, Tschopp J. DEteCTINg fungal pathogens. Nat Immunol 2007;8:17-8.

42. Stempin CC, Dulgerian LR, Garrido VV, Cerban FM. Arginase in parasitic infections: macrophage activation, immunosuppression, and intracellular signals. J Biomed Biotechnol 2010;2010:683485.

43. Dulgerian LR, Garrido VV, Stempin CC, Cerban FM. Programmed death ligand 2 regulates arginase induction and modifies Trypanosoma cruzi survival in macrophages during murine experimental infection. Immunology 2011;133:29-40.

44. Mosser DM, Edwards JP. Exploring the full spectrum of macrophage activation. Nat Rev Immunol 2008;8:958-69.

45. Martinez FO, Helming L, Gordon S. Alternative activation of macrophages: an immunologic functional perspective. Annu Rev Immunol 2009;27:451-83.

46. Raes G, Noel W, Beschin A, Brys L, De BP, Hassanzadeh GH. FIZZ1 and $\mathrm{Ym}$ as tools to discriminate between differentially activated macrophages. Dev Immunol 2002;9:151-9.

47. Giordanengo L, Guinazu N, Stempin C, Fretes R, Cerban F, Gea S. Cruzipain, a major Trypanosoma cruzi antigen, conditions the host immune response in favor of parasite. Eur J Immunol 2002;32:1003-11.

48. Chieppa M, Bianchi G, Doni A, Del PA, Sironi M, Laskarin G, Monti P, Piemonti L, Biondi A, Mantovani A, Introna M, Allavena P. Cross-linking of the mannose receptor on monocyte-derived dendritic cells activates an anti-inflammatory immunosuppressive program. J Immunol 2003;171:4552-60.

49. van Liempt E, van Vliet SJ, Engering A, Garcia Vallejo JJ, Bank CM, Sanchez-Hernandez M, van Kooyk Y, van Die I. Schistosoma mansoni soluble egg antigens are internalized by human dendritic cells through multiple C-type lectins and suppress TLR-induced dendritic cell activation. Mol Immunol 2007;44:2605-15.

50. Lopez-Herrera A, Liu Y, Rugeles MT, He JJ. HIV-1 interaction with human mannose receptor (hMR) induces production of matrix metalloproteinase 2 (MMP-2) through hMR-mediated intracellular signaling in astrocytes. Biochim Biophys Acta 2005;1741:55-64.

51. Tachado SD, Zhang J, Zhu J, Patel N, Cushion M, Koziel H. Pneumocystis-mediated IL-8 release by macrophages requires coexpression of mannose receptors and TLR2. J Leukoc Biol 2007;81:205-11.

52. Fernandez N, Alonso S, Valera I, Vigo AG, Renedo M, Barbolla L, Crespo MS. Mannose-containing molecular patterns are strong inducers of cyclooxygenase-2 expression and prostaglandin E2 production in human macrophages. J Immunol 2005;174:8154-62.

53. Zhang J, Zhu J, Bu X, Cushion M, Kinane TB, Avraham $\mathrm{H}$ et al. Cdc42 and RhoB activation are required for mannose receptor-mediated phagocytosis by human alveolar macrophages. Mol Biol Cell 2005;16:824-34. 
54. Zhang J, Zhu J, Imrich A, Cushion M, Kinane TB, Koziel H. Pneumocystis activates human alveolar macrophage NF-kappaB signaling through mannose receptors. Infect Immun 2004;72:3147-60.

55. Beharka AA, Gaynor CD, Kang BK, Voelker DR, McCormack FX, Schlesinger LS. Pulmonary surfactant protein A up-regulates activity of the mannose receptor, a pattern recognition receptor expressed on human macrophages. J Immunol 2002;169:3565-73.

56. Zhang J, Tachado SD, Patel N, Zhu J, Imrich A, Manfruelli P, Cushion M, Kinane TB, Koziel $\mathrm{H}$. Negative regulatory role of mannose receptors on human alveolar macrophage proinflammatory cytokine release in vitro. J Leukoc Biol 2005;78:665-74.

57. da Silva CA, Chalouni C, Williams A, Hartl D, Lee CG, Elias JA. Chitin is a size-dependent regulator of macrophage TNF and IL-10 production. J Immunol 2009;182:3573-82.

58. Gazi U, Martinez-Pomares L. Influence of the mannose receptor in host immune responses. Immunobiology 2009;214:554-61.

59. Kahn S, Wleklinski M, Aruffo A, Farr A, Coder D, Kahn M. Trypanosoma cruzi amastigote adhesion to macrophages is facilitated by the mannose receptor. J Exp Med 1995;182:1243-58.

60. Soeiro MN, Paiva MM, Barbosa HS, Meirelles MN, Araujo-Jorge TC. A cardiomyocyte mannose receptor system is involved in Trypanosoma cruzi invasion and is down-modulated after infection. Cell Struct Funct 1999;24:139-49.

61. Upham JP, Pickett D, Irimura T, Anders EM, Reading PC. Macrophage receptors for influenza A virus: role of the macrophage galactose-type lectin and mannose receptor in viral entry. J Virol 2010;84:3730-7.

62. DeSchoolmeester ML, Martinez-Pomares L, Gordon S, Else KJ. The mannose receptor binds Trichuris muris excretory/secretory proteins but is not essential for protective immunity. Immunology 2009;126:246-55.

63. Akilov OE, Kasuboski RE, Carter CR, McDowell MA. The role of mannose receptor during experimental leishmaniasis. J Leukoc Biol 2007;81:1188-96. 